\title{
Oral Archives Collection Problems
}

\author{
Qun Li \\ Ji Lin of China
}

\section{Keywords: Oral archives Work Value}

\begin{abstract}
Oral Archives collection is not only to remedy the defects of the traditional archives collection, but also rich collections, record information such as history, science and technology, provide a reference for national or personal development. Paper to understand the concept of oral archives, accurate analysis based on its content and features, combined with the present situation of archival management, oral archives during the collection process in the face of questions raised, and specific questions presented oral archives and constantly improve the countermeasure and the suggestion.
\end{abstract}

\section{Overview of Oral Archives}

The Meaning of Oral Archives. Since its introduction the concept of oral archives are archives of contention on the oral archives of identity and deny both sides, and the author is biased towards the latter, so later are all based on this discussion. Concepts are thought to reflect the essence of things, which is perceived by the common abstracted nature of things, be summed up, becomes a concept, connotation and extension of the concept, and changes with the development of subjective and objective world. Concept is the basis of understanding things, talk about legal evidence value of oral archives, we knew by heart the concept of oral archives first, to further discussion on other aspects of the content of the oral archives.

\section{Characteristics of the Oral Archives.}

\section{Personalized}

Oral history is not a State, community, industry, national history of a whole, but to each individual's experience, see, hear and feel. But the record events perspective and an individual's viewpoint there is a gap, not Plenipotentiaries the lives, thoughts and experiences of each individual.

\section{Diversification}

The purpose of studying history is to reveal the truth, the truth is only one, but historical events are complex, involving many people, each story. Respond differently to be inevitable, of course, the same thing. From another perspective, comprehensive investigation as far as possible, the truth is only one, different story-rich history, said living history, because history is not uniform, not a person's history.

\section{It is not Clear}

For files in different characters, time and place of collection of data, a lot of oral archives cannot form a mechanism for a systematic process. There are also many words of oral archives, each archive dictate people's experience, level of life and memories of events, will have a different factual description and narration. There's more or less a fictitious or exaggerated degree, therefore, oral archives there is ambiguity.

\section{The Existing Problems in Oral Archives Collection}

\section{Lack of Professional Personnel}

Oral archives are mainly collected through interviews, whether for a single interview or a number of people interviewed, it is a highly technical activities. It requested interviews with people not only want to understand basic interview skills can be timely in the interview guide interviewee, collected valid content; but the reality is that archives the existing lack of talents, due to the existing training system is not perfect, the lack of opportunities to learn other skills. In the recruitment of staff, limited recruiting archives professionals. Baoding fume oral Archives collection, for example, staff working in the South of Baoding archives, their business of archives is very familiar with and 
experienced, can meet the General Archives. But at the time of collection of oral archives not proficient knowledge of psychology, interview skills, photography and other related technologies. So when we collect oral archives, because they lack the talent to match, oral Archives collection results are unsatisfactory.

2. Oral Archives Collection Mechanism is not Perfect

Oral Archives collection is a complex project, to do the work is not just relying on archives could be finalized, the attention it required superior leadership and relevant departments to help, as well as for the community experts and lovers of the oral archives help to complete. As most of our local archives have not been able to establish emergency response solutions, easily lead to the urgency of the matter could not be effective when dealing with, causing the value of oral archives as "living archive" death cannot be preserved.

3. Oral Archives Collection of Environmental Chaos

In fact our country has not introduced a nationwide applicable standard of oral Archives collection, makes the local archives for oral Archives collection work when no standard reference, to a certain extent, causing the collected oral lack scientific authenticity, and prone to excessive consumption of resources. Since there is no collection of related standards as a reference, we are in the process of working with a detailed plan, but broad, some in the finish after the discovery have been missed out. Gathering up none of the content on how to identify the appropriate standard, without legal authorization, and so on. The emergence of these problems would not affect the work of the whole process, but it may cause some risks appear, especially when they lack legal authorization, published, without respondents agreed that the respondents, may have been his subject's complaint.

\section{Oral Archives to Collect Funds}

Oral Archives collection quality largely depends on the availability of funds as security. The expenditures include the cost of labor, equipment costs, travel expenses, accommodation, meals, making the transcripts of the oral archives, communications, interviews, etc. Adequacy of these costs directly affect the quality of the oral archives can be guaranteed. But the current situation is for us to archive less funding compared to other sectors, to maintain daily operations.

\section{The Oral Archives Collection Policy}

1. Strengthen the Construction of Talents Team

Priority use of high moral character, knowledge, and talents with practical experience, encourage, support for Archives staff to participate in various forms of education. Meanwhile, collection main role into full play, strengthen with archives at all levels, universities and archives society, historians and other related departments of communication and cooperation, and form all industries and all sectors involved in the oral archives of new pattern.

2. Establish and Perfect the Oral Archives Collection Mechanism

Built archives society of multivariate operation mechanism. Although oral Archives collection relating to Archives Department, history department, cultural institutions and other subjects, but it should be clear archive sector as the main responsibility of oral Archives collection. Archival departments should effectively assume the responsibilities and obligations of social construction of memory, actively cooperate with the community efforts. At present, our country has not set up a special oral archives institutions, by level and type of file is separate from the main work completed, not conducive to the collection of specialized to a certain extent, systematic and intensive development. We can draw lessons from foreign successful experience, such as oral Archives collection center in the national archives of Singapore, oral archives collections included in the overall planning of resource construction of archives, set up a special fund to increase financial support to ensure good operation of oral Archives collection.

3. Archives Collection Laws and Regulations, and to Optimize the Environment

National Archives to learn from the advanced experience of foreign countries on the basis of developed step by step in line with China's national conditions and industry characteristics of oral Archives collection of standards and specifications, clear definition of oral archives, collection content and scope, principles for assessing oral archives and archiving criteria guiding opinions. 
Meanwhile, to enact laws to safeguard the system as soon as possible, in the interview of rights and obligations between the parties, the legal powers of attorney signed, collecting work incentives, the use of oversight procedures and the sponsor should follow the specifications of providing legal support, oral archives in the collection process, guidance, keeping aspects of rules of practice.

4. Increased Oral Archives Support.

Oral Archives collection quality largely depends on the availability of funds as security. The expenditures include the cost of labor, equipment costs, travel expenses, accommodation, meals, making the transcripts of the oral archives, communications, interviews, etc. Adequacy of these costs directly affect the quality of the oral archives can be guaranteed. But the current situation is for us to archive less funding compared to other sectors, to maintain daily operations.

\section{Summary}

Above all, oral archives in the history of humanity and assumed a very important role in local development-building, but oral Archives collection process is quite complex, and the collection of archives at the lack of information on the effectiveness of, and due to the pursuit of a piece of history as well as events and oral archives collects the correlation degree of staff, leading to oral Archives collection of great twists and turns. But oral Archives collection has an important role, so the problems for discussion and study of the oral Archives collection, and propose suggestions and countermeasures of oral Archives collection plays a certain role in promoting.

\section{References}

[1] Meng Chen. Digital archives on privacy protection issues in the run [J]. Hubei archives. 2011 (9): 53.

[2] Xiangyin Yang, Xiaona Xia. Development trends of Western theories and methods of oral history - based on several important Western oral history book review [J]. Social sciences abroad. 2011 (4): 46-47.

[3] Ge Yang. On several characteristics of oral history methods [J]. Journal of Chifeng University (Chinese philosophy and social sciences Edition). 2010 (8): 101.

[4] Wenjing Sun. Discussion on problems and countermeasures of archives collection [J]. Science and technology archives. 2014 (2): 12-17.

[5] Xiaobei Liu. Oral archives work ideas [J]. Archive time. 2008 (8): 73-74.

[6] Jingbo Li. Reflections on the Archives collection work under the information environment [J]. Pure (mid-on). 2017 (4): 59-61.

[7] Yanqiu Li. On how to strengthen University Archives collection [J]. Modern communicative. 2015 (11): 63-64.

[8] Weidan Zhong. Study on Archive collection [J]. Heilongjiang archives. 2014 (6): 82-83.

[9] Hongyan Li. Status quo and countermeasure of archives collection in higher vocational colleges [J]. Science and technology horizon. 2015 (25): 77-79

[10] Hailun Yin. Thought of enterprise Archives collection work under the new situation [J]. Journal of the history of Heilongjiang .2015(13):22-24. 